\section{Call for Papers: 1993 Annual Meeting}

Paper proposals and offers to appear as discussants or panel chairs should be submitted as soon as possible. The deadline for receipt of submissions is December 1, 1992. Proposals for whole panels are welcome, but persons with suggestions for panels should get their requests in early.

Please write directly to the appropriate Program Committee section head listed below. More general inquiries or suggestions may be addressed to the Program Co-Chairs or to Jennifer Hacha, Convention Manager, APSA, 1527 New Hampshire Ave., NW, Washington, DC 20036.

Prospective participants should be aware of two APSA Council policies:

\section{Acceptance of a proposal by the} Program Committee obligates you to preregister (with appropriate fee) prior to June 1,1993 . If you fail to preregister, you will not be listed in the full program.

2. Participants may appear on two (but no more than two) panels in any capacity-chairing a panel, acting as discussant or presenting a paper. This rule applies to APSA Program Committee panels (including the Organized Section Panels) and Related Group panels.

If you apply to several Program Committee sections, please inform each section leader that yours is a multiple application. Also, in that case, please notify the other sections as soon as you have accepted an invitation for participation in another section. Proposals for papers should include author, title, and an abstract.

\section{Program Theme: "The Politics of Identity"}

Political behavior turns on identity: the actor's definition of that self which is linked to political life. The events of our time bring out ever more forcefully long standing debates over the sources and consequences of identity, be it at the level of individual, group, state or supra-national loyalties. Political theory, political research, and political action all turn on understandings of human nature. Political scientists and political entrepreneurs rest their careers on competing evaluations of how individuals define their identities, their public or private selves, their personal expression through politics. What claim for affiliation links an individual to others to form the basis for political action? Is it the political globe, the ecosphere, the nation, international institutions, race, class, ethnic group, gender, family, profession, party, religion? What causes such identifications? Is it reason, experience, profession, history, ideology, skin color, wealth, perceptions, education, hormones?

New nations are emerging; old nations seek to federate; states participate in a myriad of international institutions and arrangements. Both old and new civilizations rework the meaning of important concepts, e.g., modernity, democracy, industrialization, individual rights, equality. The international economy links conflict and cooperation issues of ethnicity, culture, and race. The movement of people, capital, and goods puts race, gender and ethnicity into politics everywhere, but the salience, or temperature gradients of these issues vary considerably. Some international claims for identity have spread like wildfire: ecology, human rights, peace. Others have faded: bolshevism. Some religions mobilize for political action; other religions appear to have little relevance for politics.

Our practice of political science as a discipline faces profound challenges by debates over identity. Do we have the appropriate methodologies, the best research strategies, the most useful theories for looking at these questions? A notion of "interests" shapes much of our work. Can the concept of self-interest include the research agendas dealing with social movements, gender, ethnicity, class, the environment, multinational institutions, and other claims to the definition of self? Or are there other theories and methods that compel attention? So important are these debates, this meeting of the American Political Science Association pays special attention to the politics of identity.

\section{Program Committee}

Program Co-Chairs: Paula D. McClain, Woodrow Wilson Department of Government and Foreign Affairs, 232 Cabell Hall, University of Virginia, Charlottesville, VA 22901; (804) 924-3614; Fax: (804) 924-3359; Bitnet: pdm6t@virginia.edu; Internet: pdm6t@watson.acc.virginia.edu.

Peter Gourevitch, Dean, Graduate School of International Relations and Pacific Studies, University of California, San Diego, 9500 Gilman Drive, LaJolla, CA 92093-0519; (619) 534-0357; Fax: (619) 534-3939; Bitnet: pgourevi@ucsd.edu.

Political Thought and Philosophy: Historical Approaches. Richard Dagger, Department of Political Science, Arizona State University, Tempe, AZ 85287-2001; (602) 965-1316; Fax: (602) 965-2012.

Although all paper and panel proposals bearing on the history of political thought are welcome, the section organizer wants especially to encourage submissions in three broad, and not entirely distinct, areas.

The first area includes the traditional concern for important political thinkers and ideas and the appropriate ways to read and understand them. This provides room for panels dealing with questions of historical method and interpretation as well as the usual panels and papers on the so-called canonical figures-and even papers on figures who ought, in the paper-giver's view, to be elevated to canonical status. Proposals dealing with the development and use of key concepts-Begriffsgeschicte in its Teutonic variant-are also welcome. In this case, one may concentrate on a particular concept, such as authority, obligation, or representation, or examine the historical connections between two or more concepts. How is it, for instance, that two concepts so closely related as government and state have both come into wide use? What can we learn about the distinction between the two from a study of their histories?

The second area comprises proposals that connect topics and concerns in the history of political thought with the convention's Pro- 
gram Theme, The Politics of Identity. There are many possibilities here, among them panels that explore the origins and history of nationalist thinking, the concern for community and citizenship, and related questions involving gender, race, ethnicity, and/or religion.

These are all matters of contemporary interest, of course, as are the topics in the third broad area, in which the history of political thought is somehow brought to bear on contemporary concerns. In this case panels and papers may look to history to shed light on such topics as the debate between liberals and communitarians, theories of distributive justice, or the ecological crisis (or crises). A panel on the sources of contemporary communitarianismHegel? the classical republicans? medieval Christian thinkers? all the above?-may prove instructive, for example, as may a panel on the putatively Hegelian theory of the end of history advanced by Frances Fukuyama.

Proposals that somehow manage to fall outside these three areas, yet still relate to the history of political thought, will also receive serious consideration. Proposals for papers that examine methods and problems of teaching the history of political thought are especially welcome. In any case, those who propose papers or panels should indicate whether (1) they are also submitting their proposals to another section and (2) there are any constraints on their participation or that of potential panelists.

\section{Normative Political Theory. Seyla} Benhabib, Graduate Faculty, New School for Social Research, 65 Fifth Avenue, New York, NY 10003; (212) 229-5759; Fax: (212) 227-5315.

In the last two decades a new kind of politics has emerged in most capitalist industrial democracies. Major transformations have occurred in the nature of issues and questions now defined as being political concerns; the struggles over wealth, political position and access which characterized bourgeois and working-class politics have been replaced by struggles over abortion and gay rights, ecology and the consequences of new medical technologies, cultural and collective identities and assertions of difference. These new issues have been represented by novel groups of political actors: instead of parties, organizations and associations there has been a shift to movement politics and to loosely coalesced groups of activist women, people of color, gay individuals, and concerned citizens. Methods of political contestation, representation and struggle have also changed. As extra-institutional channels of political contestation have ascended, politics has taken on a more personal, aesthetic and at times carnivalesque quality.

The emergence of this new politics throughout the seventies and eighties was accompanied and partly influenced by the development of currents of thought like feminism, postmodernism, deconstruction, neopragmatism. The new politics and these currents of thought have much in common. They share (1) a critique of the view of the self as a rational, goal-pursuing and utility-maximizing agent. The vision of the self and the representation of agency currently influential is that of a fractured, heterogeneous presence, motivated by many diverse and opaque impulses and shaped by allegiance to many and diverse constitutive communities. (2) Both intellectually and politically a new skepticism toward the vocabulary and conceptual framework of the democratic tradition has spread: concepts of rights and entitlements, the legal vision of the person, and the vocabulary of contract and consent have all been criticized. (3) The philosophical critique of the Enlightenment pursued by these new currents has implications for the foundations of democratic theory. Does democratic theory rest on allegedly defunct 18 th century theories of consent, the general will and rational self-interest? Can the idea of a democratic citizen, entitled to the enjoyment and exercise of rights, be formulated without a foundationalist epistemology? The new politics of identity and difference thus poses fundamental epistemological and political challenges to democratic theory and practice.

In view of the world-wide movement toward democracy and the resurgence of constitutional liberal democracy as the favored form of government by previously communist-dominated regimes, the question of the theoretical foundations of democracy and the institutional and constitutional possibilities for accommodating the politics of identity gain new actuality. Under the heading of "democracy and the politics of identity and difference," I would like to invite you to reflect upon the following issues.

1. The changing boundaries of the political. Can "identity" be a political issue, why or why not? What changes in the nature of politics as hitherto understood when "identity" becomes the center of politics?

2. Changing conceptions of the democratic citizen and the legal person. What theories of rationality and motivation have hitherto governed our conceptions of the democratic citizen and the legal person? How are these changing through the contributions of the women's and gay movements, post-modernist philosophies, etc.? Here are a set of issues dealing with political psychology and anthropology. What views of the self are replacing older conceptions of human nature?

3. Ideal of the body politic and universal citizenship. Does democracy rest on homogenizing models of identity? What does the "body" of the politic look like? Can the ideal of universal citizenship accommodate difference? These questions can be treated both historically and analytically. Discussions of specific historical transformations (i.e., old and new revolutions) and experiences of social movements in which questions of collective identity are explicitly thematized would be most welcome.

4. Conceptualizing identity/differences and democratic constitutions. The politics of "difference," which is the consequence of politics of identity, is problematical: is all difference -ethnic, national, linguistic, racial and sexual-to be respected? Are there differences among differences which make some more compatible with democratic politics than others?

\section{Foundational Political Theory.*} Susan Hekman, Department of Political Science, Box 19539, University of Texas at Arlington, Arlington, TX 76012; (817) 273-3982; Fax: (817) 273-2525. 
Historically the Foundations of Political Theory Section has addressed issues that unite political theory with the empirical concerns of most political scientists. The theme of this year's program, the politics of identity, is particularly relevant to this attempt to unite theory and practice. The politics of identity, while raising issues central to political theory, has also profoundly affected all aspects of the discipline of political science.

I would like to see many of the Foundations panels for this year concentrating on the intersection of the theoretical and practical/political questions stemming from the politics of identity. Some of the questions we might pursue are: Is the politics of identity a useful strategy for minorities and/or women who seek equality in the political arena? What are the theoretical and political origins of the politics of identity? How does identity politics relate to the modernism/ postmodernism debate and to the traditional concerns of political theory? What is the relationship between difference and identity in both theory and practice?

In addition to paper and panel proposals that deal specifically with the politics of identity, proposals concerned with other topics germane to the Foundations section are also welcome. Recent political events have generated a multitude of questions about the intersection of both traditional and non-traditional political theories and the discipline of political science. Finally, I would also like to include at least one panel on strategies for teaching these issues.

\section{Formal Political Theory. David} Austen-Smith, Department of Political Science, University of Rochester, Rochester, NY 14627; (716) 275-2338; Fax: (716) 271-1616.

Formal political theory seeks insights into collective choice processes by making explicit assumptions about individual behavior and constraints under which they act, and then logically deriving propositions from these assumptions. As such, formal political theory is a method rather than a field in its own right and panels will, for the most part, be organized accordingly. Most of the formal theorv literature to date has been concerned with U.S. political phenomena of various sorts, and I intend to continue to support panels centered on formal models of U.S. electoral, legislative, judicial and bureaucratic institutions. However, panels on other less well-trodden topics will be very welcome. I am especially interested in panels exploring aspects of political systems other than the U.S. and, more generally, in formal models addressing issues in comparative politics, international relations and international political economy.

In addition to primarily theoretical papers, papers that attempt to test predictions of extant formal models empirically are also welcome. In particular, I hope to be able to schedule at least one panel of papers reporting experimental tests of models.

Proposals for panels are encouraged, but they should be submitted well before the deadline for proposals for papers. Requests to serve as discussants or chairs are also welcome.

Political Methodology.* William D. Berry, Department of Political Science, Florida State University, Tallahassee, FL 32306-2049; (904) 6445727; Fax: (904) 644-4041. Bitnet: wberry@fsuavm. Internet: wberry@avm.cc.fsu.edu.

I intend to include some papers that develop new methodologies or approaches to research (quantitative or nonquantitative), and some papers that apply existing methodologies in an innovative fashion to study substantive political science questions. Papers about a wide range of topics are welcome, including time-series analysis, panel and cross-sectional techniques, experimental and quasiexperimental designs, simulation methodologies, survey research methods, formal theory, scaling techniques, models for discrete data, maximum likelihood methods, ecological inference, estimation problems, measurement and specification error, selection bias, and other topics. I would also like to receive proposals for papers that assess the state of the field of political methodology, or define an agenda for research topics critical to the development of the field. Questions that might be considered include: (1)
What methodological problems are unique to political science? (2) Do some fields within political science face unique methodolgical problems? (3) How are the substantive findings in various fields influenced by the methodological choices made by scholars in the area?

In addition to proposals for papers, I welcome suggestions for roundtable discussions, and offers to serve as discussants and/or panel chairs. I will be especially receptive to proposals for integrated panels; such proposals could be for "complete" panels or for "partial" panels to which other individual paper proposals could be matched. I am also happy to consider ideas for panels that might be cosponsored by other organized sections.

Legislative Studies.* Steven S. Smith, Department of Political Science, 1414 Social Sciences, University of Minnesota, Minneapolis, MN 55455; (612) 624-6820; Fax: (612) 626-7577.

The diversity of legislative studies will once again be celebrated in the section's panels. Proposals for papers, panels, and roundtables in all areas of legislative politics are welcome. Panels are likely to be formed on state and local legislatures, the U.S. Congress, and legislatures in non-American systems. I will be particularly receptive to proposals on two subjects.

First, I would like to see panels on the development of legislative institutions in new democracies. New institutions in Latin America, eastern and central Europe, and elsewhere give us the opportunity to test and further develop theory about processes of institutional change. Panels may address the legislature in the context of constitutional, electoral, and party systems, as well as the component parts and processes of legislative politics. I would like to see panels composed of both legislative and comparative politics specialists.

Second, I would like to see panels on the evolution of American legislative institutions, particularly the U.S. Congress. The 1993 program is an opportunity to bring together several avenues of historical research on Congress.

Requests to serve as panel chairs or discussants are welcomed. 
Presidency Research.* Stephen J. Wayne, Department of Government, Georgetown University, Washington, DC 20057; (202) 687-5908; Fax: (202) 687-5858.

Students of the presidency have witnessed cycles of criticism and praise for the institution and those who have served in it. At the time for this annual call for papers for the next APSA meeting, we seem to be in one of the gloom and doom cycles in which complaints and laments about the presidency and presidential leadership overwhelm the faint praise that is infrequently sounded. Is the presidency broke, and if so, how can it be fixed? What implications might "fixing" it have for the institution and the political system in which it operates? Obviously the subject of presidential leadership remains of central concern here. I hope some of you will direct your research and apply your findings to this issue of governance and the role of the presidency within the contemporary system.

Congruent with the theme of the meeting, we also need to address the topic of identity of or in the presidency. Is there an identity problem or crisis? How can presidential imprints be made and sustained within and beyond an administration? An examination of legacies would certainly be appropriate as would an examination of the methodologies by which we identify and evaluate responsibility, accountability, and accomplishments.

Although I would like to see more applied research on the American presidency, I certainly am sensitive to the continuing need for good theoretical and comparative research. Both will be welcome as will any quality proposal.

Creativity in panel format is also encouraged. In addition to the presentation of formal papers with critics, I would like to see several structured discussions (perhaps composed of practitioners and political scientists and/or other social scientists or humanists) on topics of contemporary relevance. Roundtables with short talking papers are another possibility. Let's create an exciting intellectual environment in which we can all contribute, learn, and be stimulated for another academic year. I look forward to hearing from anyone who is interested in organizing or participating in these sessions.

Political Behavior. Steven E. Finkel, Department of Government and Foreign Affairs, 232 Cabell Hall, University of Virginia, Charlottesville, VA 22901; (804) 924-6994; Fax: (804) 924-3359; Bitnet: sef@virginia; Internet: sef@virginia.edu.

Proposals are invited for papers or panels in all areas of political behavior, including electoral behavior, public opinion, political psychology, political socialization, and political participation. I expect there to be several panels devoted to the 1992 and other recent elections in the United States, but I would also welcome submissions that propose analyses of voting behavior outside the United States, and analyses of non-electoral behavior in the United States or other national settings. Papers exploring the linkages between mass opinion or behavior and public policy and broader aspects of political systems are also invited. In keeping with the theme of this year's conference, papers and panels involving the effects of racial, class, gender or other self-identifications on public opinion, voting behavior, and other types of political action will be given strong consideration.

Aside from sessions devoted to these substantive concerns, I would welcome panel or roundtable proposals dealing with the current state and direction of theoretical and empirical research in the field, evaluating the contribution of various methodological approaches, and at least one panel will be devoted to issues or problems related to teaching political behavior in and out of the classroom.

If you wish to suggest a panel on these or other topics, please contact me well before the deadline. Paper proposals should include author, title and abstract, as well as an indication if the paper is being sent to another section.

Political Parties and Organizations.* Mark J. Wattier, Department of Political Science, Criminal Justice, and Legal Studies, Murray State University, Murray, KY 42071; (502) 762-2695; Fax: (502) 762-3482; Bit- net: Aø3222F@MSUMUSIC.

The theme of the 1993 annual meeting is "the politics of identity," its definition, and the consequences thereof. The causes and consequences of social and political identities have been studied by such noted authors as Murray Edelman (The Symbolic Uses of Politics), Erving Goffman (The Presentation of Self in Everyday Life), Harold Lasswell (Psychopathology and Politics), and George Herbert Mead (Mind, Self, and Soci$e t y)$. Such studies typically explore several questions about personal identity: Who am I? Who do I want to be? What am I worth?

Proposals for both papers and panels are, therefore, solicited which address themselves to how political parties and other organizations-interest groups, social movements, PACs, campaign organizations, etc. -construct their identities. Theoretical, empirical, and pedagogical investigations of this general problem are welcome. Of special interest are studies of how group leaders and group members construct both individual and collective identities within organized contexts. Possible topics along these lines include, but not need be limited to, the following:

- What, if any, new and interesting questions does "political identity" suggest for students of parties or groups or social movements?

- Is "political identity," a concept with demonstrated utility for microlevel studies, a relevant concept for macro-level studies of parties, groups, or social movements?

- Must one use only unconventional or novel theoretical approaches - symbolic interactionism, ethnomethodology, or schema theory, to name a few - to study parties, groups, or movements in terms of their identities?

- How may studies of parties, groups, or movements define political identity in concrete, operational, and observable terms?

- To what extent do partynomination processes, conventions, platforms, and general-election campaigns define political identities of leaders, followers, and party coalitions?

- To what extent, if any, do other organizations-particularly news organizations-influence political 
identities of group leaders and followers?

- What organizational structuresWeberian, Barnardian, etc.-create and sustain the construction of identities that engender both individual growth and organizational effectiveness?

- What are the sources and consequences of the "identity crisis" of PACs? What, if anything, have PACs done to ameliorate this problem?

- How and why have various social and political movementslabor, environmental, civil rights, gay rights, feminist, etc. - created political identities that either promote or impede their political objectives?

This list is meant to be suggestive, not exhaustive. Theoretical, methodological, and pedagogical pluralism reigns in this APSA section, and I do not wish to impose any dogma or orthodoxy-save scholarly excellence and the timely submission of papers-upon its membership. I welcome your suggestions on whether political identity either creates new puzzles or offers new solutions for students of political parties and other political organizations.

Law and Courts.* Lee Epstein, Department of Political Science, Washington University, Campus Box 1063, One Brookings Drive, St. Louis, MO 63130-4899; (314) 9358580; Fax: (314) 935-5856; Bitnet: C38054LE@WUVMD.

I invite paper and panel proposals on all aspects of courts, law, and judicial processes. I hope to encourage a range of submissions reflecting the subsection's heterogeneity. Some panels will, of course, contemplate topics that are generally distinct to our field. These might include local courts and dispute resolution, lawyers, judicial impact and implementation, and historical and contemporary analyses of federal appellate courts. Along these lines, I am particularly interested in receiving proposals on state judicial systems and on comparative legal processes. I also envision panels that bridge our subsection to others. Accordingly, I welcome proposals on topics such as the politics of identity (the 1993 program theme), courts and public opinion, interest group involvement in the legal system, and relations among executives, legislatures, and judiciaries. I also encourage papers that are methodologically or theoretically innovative.

I specify these topics to be suggestive, not exclusive. I look forward to receiving other ideas for papers, entire panels, or roundtables. If you would like to serve as a discussant or chair, please indicate your areas of interest and expertise.

\section{Constitutional Law and Jurispru-} dence. Sue Davis, Department of Political Science, University of Delaware, Newark, DE 19716; (302) 831-1934.

The Politics of Identity, the theme of the 1993 program, suggests a wide variety of approaches and topics in the field of constitutional law and jurisprudence. Proposals are invited for papers, panels, and roundtables that focus on relatively new theoretical approaches, such as feminist jurisprudence and critical legal studies, as well as work that utilizes more traditional doctrinal analysis of developments in constitutional law.

Proposals are especially welcome on historical and contemporary analysis of the Supreme Court, judicial biography, constitutional developments in state supreme courts and lower federal courts, comparative constitutional law, constitutional interpretation, the role of the Senate in the judicial selection process, recent appointments to the Supreme Court; and work in substantive areas of constitutional law, such as conservatives' use of freedom of expression and equal protection to challenge policies that seek to protect the rights of minorities and women, affirmative action, reproductive rights, pornography, recent developments regarding habeas corpus, and property rights. Proposals on teaching constitutional law and jurisprudence are also encouraged.

We hope that many of the proposals will reflect the theme of The Politics of Identity in creative and innovative ways. All proposals will be seriously considered, however. Every effort will be made to include panels that reflect the rich diversity of work in constitutional law and jurisprudence.
Also welcome are offers to serve as chair or discussant-please indicate substantive areas of interest.

Public Administration.* Hal G. Rainey, Department of Political Science, Baldwin Hall, The University of Georgia, Athens, GA 30602; (404) 542-2057; Fax: (404) 542-4421.

The conference theme raises many possibilities for addressing its relations to topics on which members of our section do excellent work. Some examples include the following: the role and image of the administrative branch and administrators; administrative behaviors and attitudes (such as service motivation, leadership, commitment, and professionalism); the relations between administrative agencies and citizens; ethics; decisionmaking and policymaking; oversight, accountability, and the political environment of administration; administrative capacity and performance; administrative structure (including intergovernmental and interorganizational structure and process); alternative modes of administration and service delivery (privatization, contracting, government by proxy); and various substantive topics or areas such as regulatory administration. Other possibilities include papers and panels concerning theory development, and methodological and paradigmatic issues in relation to the theme and/or the foregoing topics. The APSA national office encourages panels on teaching topics under the purview of the sections, so interested persons please submit proposals for panels on teaching.

As indicated, this list offers examples, without intending to prescribe or proscribe. Any good idea is welcome.

Federalism and Intergovernmental Relations.* Beverly A. Cigler, Public Policy and Administration, Penn State Harrisburg, Middletown, PA 17057-4898; (717) 948-6060-leave messages; Fax: (717) 948-6320.

Dynamic tensions and mutual adjustments among central, regional, and local governments as they "search for identity" are the focus for this organized section's panels, roundtables, and papers. Proposals on all aspects of federalism and 
intergovernmental relations in the United States and other polities are welcomed. Priority will be given to those demonstrating solid theoretical and empirical work on intergovernmental relations and federalism in the United States and other federal polities.

Paper proposals must provide an abstract that specifies details on the topic investigated, the theoretical and methodological approach used, and data sources. Proposals for panels must provide complete details on each proposed paper. For roundtables, include full information about the subject matter to be examined, as well as information about each participant. Offers to serve as chair or discussant are also welcome; provide a statement of substantive areas of interest and expertise. For all formats, also provide the title, author, address, and telephone and fax numbers for each participant. Suggestions for new formats, cooperation with other organized sections, etc. are welcome. A sincere effort will be made to accommodate paper, panel, and roundtable proposals that represent the rich diversity of work in intergovernmental relations and federalism.

Urban Politics.* Ester R. Fuchs, Department of Political Science, Barnard College, Columbia University, 3009 Broadway, New York, NY 10027; (212) 854-3866; Fax: (212) 854-3024; Bitnet: ef25@cunixa.cc.columbia.edu; and William E. Nelson, Jr., Black Studies Extension Center, Ohio State University; 905 Mt. Vernon Avenue, Columbus, $\mathrm{OH}$ 43203; (614) 292-3770; Fax: (614) 292-2293.

Proposals are invited for papers, panels, and roundtables on all aspects of urban politics. The 1990s will be a critical period for determining the political and economic viability of American cities. We would especially be interested in proposals relating to questions of race and ethnic relations, creative approaches to urban governance, political accountability, and urban political economy. Standard topics such as service delivery, public opinion, the urban-suburban divide, and federal/ state urban policy are also welcome. Paper proposals should clearly specify the topic to be investigated, as well as theoretical and methodological approaches to be used. Proposals for roundtables or panels should include a summary description of the subject matter to be examined, as well as information about prospective participants and their contributions. We also welcome offers to serve as panel chair or discussant; please let us know your areas of expertise for possible assignment to appropriate panels.

State Politics and Policy.* Dennis Brady, Department of Political Science/Criminal Justice, Appalachian State University, Boone, NC 28608; (704) 262-6344; Fax: (704) 262-2944; Bitnet: GradyDO@APPSTATE.

Proposals are invited for panels, papers, and roundtables pertaining to all aspects of state politics and policy. Given the dynamism of the states over the past decade, their unique position as a comparative laboratory for testing theories of political processes, institutions and behavior, and in anticipation of relatively limited panel space, I am particularly interested in receiving paper proposals that are comparative, theory driven and empirical. Priority will be given to roundtable and panel proposals that probe themes related to (but not limited to) issues such as: electoral and campaign finance reform, institutional development and reform, policy diffusion, fiscal constraints and mandate management, and other topics of pressing concern to state policy makers. Priority will be given to papers that: (1) examine data from several states, (2) involve the testing and/or development of empirical theories of state politics and policy, and (3) utilize new data and methods to answer important theoretical or analytical questions of interest to scholars of state politics. Proposals focusing on comparative state politics pedagogy will also be reviewed.

Proposal submitters are encouraged to provide as much information about their proposals as possible (e.g., hypotheses being tested, unit of analysis, research design and data, and current status of the research). Please remember to include name, mailing address, and telephone number on proposals. Panel and round- table proposals should include names of proposed participants with titles of proposed papers. Those wishing to participate as panel chairs or discussants should indicate areas of expertise and types of panels on which they wish to serve.

Public Policy.* Helen Ingram, Udall Center for Studies in Public Policy, University of Arizona, 802/811 E. First Street, Tucson, AZ 85719; (602) 621-7189; Fax: (602) 621-9234.

Public policy performs important functions that are critical to a democracy: public policies are intended to solve problems; public policies are supposed to represent and to reconcile competing interests and to garner support for needed actions; and public policies are supposed to enlighten and engage citizens. Ironically, at a time when democracy would seem to have triumphed over all rival forms of government, serious questions are being raised about the performance of policies in the United States and other democratic and democratizing nations. The unifying theme of this section in the 1993 program will be the consequences of policy for democracy.

The section chair welcomes proposals from researchers investigating the extent to which policies serve instrumental goals, and the factors that foster the delivery of intended consequences, avoid dysfunctional effects and promote efficient and equitable allocation of resources. Such questions have long preoccupied policy science and evaluation researchers, but have also intrigued those adopting a rational choice or institutional analysis perspective. The section program is open to assessments of policy success and failure from a variety of perspectives.

Political scientists studying public policy have often concentrated on the politics of policy and whether and how interests are represented and affected. The section chair welcomes suggestions for panels and papers that address who wins and who loses in policy and how. Hopefully the research presented in the section will address not only the politics of policymaking, but whether policies themselves evoke or discourage the emergence and mobilization of inter- 
ests. Public policies are a part of the politics of identity, the overall 1993 program theme, since policies define target groups, i.e., those included or excluded in receiving benefits and bearing burdens. The section chair is especially solicitous of proposals that address how policies reflect and shape individual and groups identity.

Ultimately a democracy stands or falls upon the character of citizenry, whether inhabitants identify themselves as such and whether they are engaged and empowered. Critical theorists and others have viewed building the capacity of citizens as the most important role of policy and have questioned whether public policy designs encourage or discourage open and discursive deliberation. Proposals that examine how policies reflect and affect citizens' identity and citizens' expectations about the role of government are eagerly anticipated.

At a time when politics and policy are widely regarded as failing in the United States and other countries, alternatives to normal and prevailing policy designs are being sought as a means for improvement: radical decentralization and/or privatization, the use of markets and incentives, new roles for agency officials and more objective techniques for identifying policy needs, grass roots problem-solving, workplace democracy and many others. Panels and papers that suggest, and/or evaluate such alternatives are particularly appropriate.

The study of public policy has traditionally had a special appeal to students, even when politics is being shunned. The section chair welcomes suggestions for papers and panels on teaching public policy, most especially if policy is the vehicle to lead students to examine the enduring political science questions of representation and democracy in setting policy agendas, and formulating and implementing policy.

Political Economy. Michael Mastanduno, Department of Government, Dartmouth College, Hanover, $\mathrm{NH}$ 03755; (603) 646-2937; Fax: (603) 646-2152.

The section on political economy promotes research that investigates the relationship between political and economic variables, integrates political and economic approaches, or uses economic models to understand political behavior. Political economy builds upon and often cuts across the traditional fields of American politics, comparative politics, international relations and political theory. It also relies on a variety of methodologies. Case studies, historical or institutional analyses, formal modeling, and quantitative or survey research are all welcome.

I will consider proposals on a wide range of topics, and will give priority to proposals that offer analyses of the relationship between states and markets, or of the tension between sovereignty and interdependence. I also welcome papers on business and government, the domestic implications of trade, technology, and capital movements, the domestic sources of foreign economic policy, theories of the state, property rights and economic development, regionalism and multilateralism in the world economy, and the relationship between economics and national security.

Women and Politics.* Susan C. Bourque, Department of Government, Smith College, Northampton, MA 01063; (413) 585-3535, 585-3591; Fax: (413) 585-3389.

Identity has been at the core of our thinking about gender and politics. To what extent do self-conceptions as female and male shape our notions of authority and leadership? Does gender shape our routes to political consciousness? to what extent does gender identity impinge on political behavior? If we recognize that ideas about gender and gender identity vary historically and cross culturally, what can we say about the relevance of gender for political life? The 1993 APSA theme "the politics of identity" provides us with an opportunity to assess our understanding of the significance of gender as a source of political identity. Panels and papers exploring the link between gender and ethnic identity on political behavior. We are viewing political Women and Politics section. It is my hope that our papers and panels will reflect cross cultural perspectives and highlight work currently underway in a variety of geographical areas and in the various areas of political science, including comparative politics and public policy.

Related to our general theme of the politics of identity, papers which address the role of governments in shaping gender identity, the relation between gender and political participation and between gender and definitions of politics itself will be welcome. I hope to include papers which link the concerns of political theory with contemporary politics in a range of societies. In addition, papers which analyze the gender implications of the 1992 U.S. elections will be of particular interest in the 1993 meeting. Similarly, I would like to include panels assessing the impact of women's political participation on policy making and implementation in both the United States and international contexts.

Panels which include at least one paper which deals with the pedagogical or teaching implications of the panel theme will be given preference. In addition, I would like to encourage panels which include a mix of junior and senior scholars and will welcome proposals for complete panels as well as individual papers.

Race, Gender and Ethnicity. Mamie E. Locke, School of Liberal Arts and Education, 119 Armstrong Hall, Hampton University, Hampton, VA 23668, (804) 727-5400; and John A. Garcia, Department of Political Science, 315 Social Sciences, University of Arizona, Tucson, AZ 85721, (602) 621-7600.

Given the continued growth of the subfield of race, gender and ethnicity in the discipline of political science, we are seeking ideas and suggestions for panels, papers, and roundtables that address the impact of race, gender and ethnic identity on political behavior. We are viewing political behavior as a wide range of behaviors in many different political arenas and contexts. Creative panels that incorporate empirical, methodological, pedagogical, and theoretical approaches appropriate to research in this area are especially encouraged and welcomed.

Panels, papers and roundtables that focus on the following are of particular interest: (1) race, gender 
and ethnicity as the basis for group identification; (2) the impact of group identity on the political process, decisionmaking, political actors and public policies; (3) cross-cultural and cross-national comparative studies; (4) the impact of identity (group identification) on the political behavior of elected officials (e.g., African American crossover politicians); (5) the socio-economic and political implications of group identity; (6) studies that incorporate data, ideas and concepts from other academic disciplines (e.g., sociology, law, history, economics); and (7) pedagogical approaches and curriculum issues relative to race, gender and ethnicity.

We welcome suggestions or ideas for panel chairpersons and discussants. Student panels are encouraged.

Politics and History. Deborah Stone, Heller School, Brandeis University, Waltham, MA 02254; (617) 736-3838; Fax: (617) 736-3881.

Proposals are invited for papers, panels, and roundtables that examine the intersection of history and politics. For 1993, topics of special interest include: (1) defining the distinctiveness (if any) of the use of historical inquiry by political scientists; (2) the relationship between ideas and institutions, and especially, the incorporation of ideology in law; (3) the contributions of political/historical inquiry to an understanding of contemporary public policy; (4) the relationships between race and class in the formation of American political structures.

As always, we will aim to make the program reflect the intellectual puzzles that preoccupy section members. We will make a special effort to ensure a mix of the usual suspects and newer members of the profession.

\section{Comparative Politics. Adam}

Przeworski, Department of Political Science, University of Chicago, 5828 South University, Chicago, IL 60637; (312) 702-8063, 702-1689.

Proposals are invited for panels that are unified by theoretical, methodological or thematic questions and bring together papers addressing these questions in a cross-national context. Papers that employ explicit models, utilize statistical methods, or are self-conscious about research design will be favored. Reflections on the sad state of comparative politics are encouraged.

I see among the topics about which much can be learned the effects of political institutions on performance and survival of regimes, the interplay between economic internationalization and domestic politics, the politics of economic reforms, as well as ethnic, linguistic, religious and class conflicts. In turn, panels on transitions to democracy will be accepted only if they have something truly new to say theoretically or methodologically.

Proposals should indicate what we are going to learn that we do not yet know and how.

\section{Politics of Developing Areas. Pearl}

T. Robinson, Department of Political Science, Tufts University, Medford, MA 02155; (617) 627-3465; Fax: (617) 627-3703; Bitnet: probinso@pearl.tufts.edu.

Proposals are invited for papers, panels and roundtables that deal with theoretical and methodological issues of concern to students of what has traditionally been referred to as Third World Politics. Given the demise of the bipolar world, we are especially interested in contributions that explore alternative configurations and/or terms of categorization. Sessions reexamining the relevance of extant approaches to this subject, as well as discussions of new conceptual, theoretical and methodological insights are particularly germane. Interdisciplinary approaches and theories that incorporate gender analysis are encouraged. Topics might include: the comparative politics of democratic transitions; the interaction of state and market reforms; opportunities and constraints in development policymaking; theoretical or empirical explorations of the boundaries between domestic, regional and international politics; the new politics of environmentalism in the LDCs; and assessments of the future of comparative political analysis of the developing areas.

Communist Regimes. Donna Bahry, Department of Political Science, Uni- versity of California, Davis, CA 95616; (916) 762-0466.

The transition from communism has changed the face of the globe from Belgrade to Moscow and beyond. The process has also highlighted the enormous challenges in creating new and enduring institutions to replace one-party rule and central planning. Panels in this section will focus primarily on the problem of institutions and state-building, broadly defined.

Proposals are welcome on any topic, but special emphasis will be given to the following: the politics of new electoral and legislative systems, and their impacts; the emergence of new parties and movements, their constituencies, and their influence; the creation of new economic institutions and their role in reducing or preserving state control; the "descent" of authority to the regional and local level, and its implications; strategies for managing the social costs of economic reform, and their effect on different constituencies; and the creation of new mechanisms of cooperation among post-communist regimes.

Proposals might also concentrate on public responses to new institutions. They may focus, too, on the politics of state-building and identity formation in newly independent postcommunist states, and especially on language, culture and communal conflict.

Papers and panels with a crossnational emphasis will be particularly welcome.

\section{Comparative Politics of Advanced Industrial States. Suzanne Berger, Department of Political Science,} E53-473, Massachusetts Institute of Technology, Cambridge, MA 02139; Fax: (617) 258-6164.

Proposals are invited for panels, roundtables, and papers on politics and society in advanced industrial countries. Several themes will be emphasized this year: politics of transitions from planned to market economies; the emergence of new parties and new party systems; the impact of the international economic system on domestic institutions and politics; the politics of race and ethnicity; ideological decline or ideological renewal?; generations and political 
change; welfare states in transition; neoliberalism; the role of the state in the shift from mass production to flexible specialization. These suggestions are not meant to limit the range of submissions; other proposals are welcome.

\section{Politics and Society in Western}

Europe. Nancy Bermeo, Department of Politics, Princeton University, Princeton, NJ 08540; (609) 258-4771; Fax: (609) 258-4772.

This year's West European section will be organized around a theme of integration and disintegration. Both of these processes might be addressed at international and national levels of analysis. Panels on international integration within the European Community would be welcome along with panels which discuss integration on a national level. These latter panels might deal with a broad spectrum of themes ranging from the integration of parties (through the formation of coalitions and alliances) to the integration of women, minorities and immigrants in politics at the local and national level. The challenges of regional integration are also of interest.

Panels which focus on disintegration might address the decline of certain political organizations (such as trade unions or political parties) or the emergence of extremist organizations which seek to challenge existing party structures and patterns of integration. Panels which deal with subnationalisms or the disintegration of traditional links between state bureaucracies and economic enterprises are also appropriate. Panels and papers which are explicitly comparative are especially welcome.

International Collaboration. Janice Stein, Department of Political Science, 110 St. George St., University of Toronto, M5S 1A1 Canada; (416) 978-1048; Fax: (416) 978-5566.

Despite the fact that international politics take place in the absence of central rule, collaboration among states is widespread. In recent years, critically important instances of collaboration may be found in the relatively stable disarticulation of the Cold War, the movement toward Europe 1992, the emergence of the global factory and integrated capital markets, and movement toward protecting the global biosphere.

Indeed, it is an interesting research question to ask whether international politics perform substantially worse in managing such transformations than do domestic political systems in managing their domestic analogues. And yet, mainstream international relations theory still considers international collaboration to be (1) epiphenomenal, or (2) the exception to the rule, or (3) of marginal significance. In the section on international collaboration, we hope to shed light on this paradox-that a seemingly widespread and important phenomenon exists which, according to the prevailing wisdom, isn't supposed to be either.

We are casting the net widely and are interested in soliciting proposals from individuals across the range of international relations: those who specialize in security studies, international political economy, international institutions, environmental issues, and human rights. Panels can be past, present, or future oriented. They can be organized around specific issue areas, specific periods, or specific analytical/theoretical problems. We especially encourage proposals for an entire panel.

\section{International Security and Conflict.} David R. Mares, Department of Political Science, UCSD, La Jolla, CA 92093-0521; (619) 534-4205.

Given the current state of flux in the study and workings of international politics, the range of topics addressed by this section is quite broad. I am particularly interested in stimulating debate about the appropriateness/desirability of new definitions of security in the post-Cold War world, the future of intraOECD relations, and the impact of the new security environment on developing countries.

Panel or roundtable topics could include: the future of nuclear weapons and arms control (including proliferation); the proliferation of other weapons and strategies to control them; the implications of declining defense budgets and other issues in defense economics for the East and West; regional conflicts and the prospects for regional approaches to resolve them; the implications of the end of the Cold War and of the Gulf War, including for weapons technology, arms exports, regional conflicts, intervention, and new missions for the armed forces of the major powers; and non-traditional security issues, such as the environment, resources, or economics. Given the breadth of issues that could be covered by panels for this section, an emphasis on the implications of continuity or change as organizing themes would be especially appropriate.

Proposals for papers, panels, or roundtables should include a brief statement of the topic or theme. Panels or roundtables that include participants from other disciplines are especially encouraged. Anyone interested in serving as a panel chair or discussant should provide information about his or her areas of research. In all cases proposals must include titles, names, addresses, and telephone numbers.

International Security and Arms Control. Stephen J. Cimbala, Penn State University, 25 Yearsley Mill Road, Media, PA 19063-5596; (215) 892-1410; Fax: (215) 892-1357.

The subject matter of this section will undergo as profound a transformation in the next decade as have the interstate and domestic security environments in the past few years. The end of the Cold War, the demise of the government of the Soviet Union, and the broader restructuring of expectations about security community within and outside Europe argue for a more complex agenda for security and arms control research during the 1990s. The traditional focus of security studies on military issues remains an important aspect of the broader compass of security related studies which is now emerging. However, already apparent are serious efforts to extend the scope of security and arms control into more explicitly political, social and economic agendas.

Proposals for papers, panels, roundtables or other formats are welcome on any of the following topics, as well as others which are suited to the general subject matter of the section.

1. Was the Cold War an essentially stable period as prominent schol- 
ars and analysts have argued, or was the Cold War actually more turbulent than many proponents of Cold War stability have supposed? Does the Cold War really support arguments that bipolarity is a more stable configuration than multipolarity? Based on Cold War and previous experience, is system polarity as important as intrastate variables in determining system stability? Is there any longer a meaningful boundary between "domestic" and "foreign" policy?

2. In a multipolar system with regionally subdivided security structures, what are the preferred regime structures for nonproliferation of weapons of mass destruction or of high technology conventional weapons? What are the promises and potential pitfalls for the Nonproliferation Treaty and for the Missile Technology Control Regime in the 1990s and thereafter? What strategies are open to potential proliferators, and what countermeasures to antiproliferators?

3. What are the prospects for transnational security community and Europe, or elsewhere, in the next decade or so? What will be the shares of responsibility for post-Cold War security in Europe taken by, for example, the EC, NATO, WEU, CSCE, or other on-state actors with interests in security? Will stability in Europe be augmented or diminished if the U.S. withdraws all of its ground and tactical air forces from NATO territory? What possibilities exist for non-offensive defense in Europe? Can NATO remain relevant within a broadened European security regime dominated by CSCE or some other body more, or less, inclusive than NATO?

4. Is there life in security, defense and arms control studies after the Cold War? If so, of what kind? Does collective security represent an important future aspect of security and arms control studies? How might historical precedents in collective security suggest either optimistic or pessimistic futures for multilateral deterrence as a substitute for unilateral, within Europe from the Atlantic to the Urals or outside of Europe? How could collective security be applied to peacemaking in the Middle East/Southwest Asia region, and, in particular, to the settlement of outstanding differences between Arabs and Israelis? Do international law and morality now play greater, or lesser, parts in supporting multilateral security regimes than before the end of the Cold War?

\section{International Political Economy.} John A. C. Conybeare, Department of Political Science, University of Iowa, Iowa City, IA 52242; (319) 335-2343; Fax: (319) 335-2070; Internet: conybearej@pspo.polisci.uiowa.edu.

Panel proposals or paper suggestions are welcome in all of the traditional functional areas of the politics of international economic relations (trade, money, multinational corporations, north-south relations, environment, etc.). Ideas are particularly welcome with regard to the following topics:

(a) Formal models which may provide new bases for theory in international political economy, or further illuminate historical or normative issues;

(b) Empirical testing of theories, using relevant statistical or other computational techniques;

(c) Use of economic history (cases or larger datasets) to shed new light on theories of international political economy;

(d) Application of explanatory or prescriptive theory to current policy issues (e.g., bargaining in GATT, aid to the former Soviet Union, UNCED).

Foreign Policy Analysis. Edward Kolodziej, Department of Political Science, University of Illinois, Lincoln Hall 361, Urbana, IL 68101; (217) 333-3880; Fax: (217) 244-5712.

Panels and papers that break new substantive, analytical, or methodological ground are particularly welcome. Areas of substantive interest include:

(a) Systemic determinants of foreign policy behavior, exemplified by shifts in global and regional balances of power in the post-Cold War era, environmental deterioration, the globalization of markets, the demands of a growing world population for greater economic welfare, democratization, and human rights;

(b) Domestic determinants of foreign policy, particularly the causal interface with systemic determinants; and

(c) Comparative foreign policy, comparing the roles of particular political actors, institutions, or movements across states and societies in affecting foreign policy behavior and policymaking.

These areas are suggestive, not exclusive or exhaustive. Panels and papers covering all topics related to the foreign policy analysis are encouraged. Policy-prescriptive panels and roundtables may also be proposed. Roundtable and panel proposals should include the names and topics of each participant and an abstract of the enterprise. Paper proposals should include an abstract of the topic.

Representation and Electoral Systems.* Lorn S. Foster, Politics Department, 1 Carnegie Building, 425 N. College Ave., Pomona College, Claremont, CA 91711; office: (714) 621-8555, ext. 2263; home: (714) 626-6400; Fax: (714) 621-8576.

A conscious attempt will be made to create a balance between those panels on domestic issues of representation and those from a comparative perspective. Two important questions will need to be answered after the 1992 election: what impact has redistricting had upon Congress and the 50 state legislatures? The other question that needs to be answered, is how did turnout impact the 1992 presidential election? After Gingles it is important that we address the question of compactness and minority representation along with the viability of biracial electoral coalitions. In the U.S. there are a few instances where the courts have mandated alternative electoral schemes as a remedy to previous racial discrimination in voting districts. It would be appropriate to evaluate the outcome of these various alternative electoral schemes. The above listed topics are not exhaustive of all the possible domestic panels on representation and electoral systems.

Most of the work done on alternative electoral systems has been done from a comparative perspective. Comparative studies dealing with the single transferable vote and proportional representation are encouraged. With the breakup of the Soviet 
Union and the creation of the CIS we now have an opportunity to examine representation and alternative electoral systems in a previously totalitarian state.

Any proposals that deal with empirical and normative theories of representation and electoral systems are encouraged.

Conflict Processes.* Steve Chan and Michael Ward, Department of Political Science, University of Colorado, Boulder, CO 80303; (303) 492-7904 (Chan); (303) 492-6405 (Ward); Fax: (303) 492-0978; Bitnet: chan_s@gold.colorado.edu or ward@spot.colorado.edu.

Conflict processes are flourishing around the globe, despite or perhaps because of some of the dramatic changes in major power behavior patterns during the past five years. Conflict processes and resolution venues have a variety of interesting theoretical, empirical, normative and practical implications. We would like to receive proposals for papers and panels that address these implications in the context of global, transnational, interstate, and domestic situations. We also wish to solicit a wide variety of perspectives spanning, but not limited to, sociological, psychological, geographic, and economic approaches.

Some examples of topics we believe to be important include: ethnic, subnational conflict evolution such as currently underway in Europe and Asia; aspects of political and institutional integration and disintegration; trade disputes and tension over international transfers of goods, services, and investments; the battle over rules of the game in old and new or emerging regimes, such as the Rio initiatives, GATT; European defense initiatives; the connection between revolutionary movements and democratic trends; domestic violence and repression; regional conflict possibilities in Asia, Africa, the Americas, and Europe; and crisis management in the context of major power detente. We welcome other, important suggestions as well.

Politics and the Life Sciences. Andrea L. Bonnicksen, Program for Biosocial Research, Social Science Research Institution, Northern Illi- nois University, DeKalb, IL 60115; (815) 753-9676 or 753-7049; Fax: (815) 753-2305.

The life sciences and politics intersect at diverse and intriguing points, and they provoke substantive and theoretical contributions to political science. Proposals for papers or roundtables on any facet of politics and the life sciences are welcome. Among the panels that might be convened are those dealing with issues in biomedical policy (including physician assisted suicide, fetal research, and genetic medicine); developments in the field of biological and chemical warfare; biotechnology regulation; biobehavioral approaches to political decisionmaking; physiological measurement of political behavior; and controversies in sociobiology.

Multidisciplinary panels are encouraged that bring together participants from the social sciences, medicine, biology, law, bioethics, and philosophy. A roundtable is another possibility with faculty and graduate students discussing innovative methods for teaching politics and the life sciences and for placing students who have expertise in both biology and political science.

Persons submitting proposals should include a one-page description and a resume or statement of research interests. Those proposing a roundtable or panel should include names of persons who might be willing to participate. Those who would like to serve as discussants should indicate this preference.

The study of politics and the life sciences is new and evolving. This year's panels give an opportunity to see both the breadth of the field and to understand more fully its contours, especially in the areas of biomedical and biotechnology policy. Integrative proposals are encouraged that look either to the substantive development of topics in politics and the life sciences or to likely future directions.

Religion and Politics. Kenneth D. Wald, Department of Political Science, University of Florida, 3324 Turlington Hall, Gainesville, FL 32611-2036; (904) 392-0262; E-mail: KENWALD@NERVM (add .NERDC.UFL.EDU for Internet);
Fax: (904) 392-8127.

As befits its diverse subject matter and methodological pluralism, the Religion and Politics Section customarily accepts papers on a wide range of topics and utilizing assorted research strategies. If past conferences are any indication, we anticipate good proposals on such perennial topics as church-state relations, religion in mass political behavior, the politics of various religious groups, religion and democracy, etc.

The 1993 Meeting offers an opportunity to assess several moments and events that inspired the current scholarly interest in religion and politics: the rise of the New Christian Right in America, the Khomeini Revolution in Iran, liberation theology, the emergence of religious opposition to oppressive regimes around the globe. What did these movements share beyond a challenge to authority in the name of transcendent values? From the perspective of hindsight, what were their fates, impact, and lessons for contemporary politics? What impact did political engagement have on religion and religious activists?

The meeting would also be a good time to revisit some perennial themes that have gained renewed attention with the resurgence of the cultural approach in political science. How do classic arguments about certain religions as obstacles to political development stack up against contemporary politics? What impact did political engagement have on religion and religious activists?

The meeting would also be a good time to revisit some perennial themes that have gained renewed attention with the resurgence of the cultural approach in political science. How do classic arguments about certain religions as obstacles to political development stack up against contemporary evidence? Under what conditions does religious intensity encourage otherworldliness, passivity, and intolerance? What is the relationship between religion and ethnic identity?

I also welcome papers that utilize methods or raise problems that are not so familiar. What role does religion play in regional choice theories? Papers on religion in locali- 
ties, religion as an international force, or religion as an influence on public policy-makers would also add to our store of knowledge.

I am open to early suggestions (October 15) for theme panels, workshops, author meets critic sessions, and roundtables. For other papers, please observe the general program deadlines.

Applied Political Science. Laslo Boyd, University of Maryland, Baltimore, MD 21228-5398; (301) 455 3666; Fax: (301) 455-1210.

Proposals for papers and panels on applied political science at the 1993 Convention should focus broadly on two areas.

Drawing upon Ernest Boyer's typology of scholarship, and specifically his concept of the "scholarship of application," proposals are invited on the role of applied political research within the discipline. Proposals might examine the standards to be used for evaluating applied political research, discuss the relationship between applied and traditional political science, and assess examples of applied political science.

The contribution of the applied perspective to the standing of political science as a profession is the second area for proposals. While individual political scientists have played important policy making roles, it is less clear that the discipline has been as widely accepted and recognized as some others in having a contribution to make. Is this generalization correct? Is it important? Would it be changed if applied political science had greater acceptance within the discipline?

\section{Science and Technology Studies.} Gary Bryner, Department of Political Science, Brigham Young University, Provo, UT 84602; (801) 378-3276; Fax: (801) 378-5730.

We welcome proposals for papers and entire panels that address science and technology from a variety of theoretical perspectives and empirical approaches. Papers that seek to contribute to the theoretical underpinnings of science and technology studies are particularly welcome. Given the interdisciplinary nature of science and technology studies, we encourage panels involving discus- sants and other participants from other disciplines.

Panels in earlier meetings have addressed the following kinds of questions: (1) What are the central concerns of science and technology studies? What are the most fruitful theoretical or conceptual approaches to understanding the political significance of science and technology? (2) What are the most relevant characteristics of science and technology for political scientists? What are the theories, conceptual frameworks, and concepts from political science that can be usefully applied to science and technology studies? What kinds of issues that are central to science and technology studies help explore the major concerns of political science? (3) What are the social properties of science and technology? What social and political institutions are central to the role of science and technology in political and social systems? (4) What challenges do science and technology-related policies pose for policy making? What are the primary characteristics of these kinds of policies? How well do the institutions of government assess the consequences of scientific and technological changes and develop appropriate policy responses? How does policy making in this area contribute to our understanding of politics and government? (5) How does policy making for different kinds of policies compare in terms of U.S. policies and cross-nationally? How is policy making for science and technology policies intertwined with international relations?

The Section also sponsors research workshops on a different topic each year the Wednesday before the APSA meetings begin, and we welcome suggestions for topics and participation by anyone interested.

\section{Computers and Multimedia Section.} Anne Permaloff, Department of Political Science and Public Administration, Auburn University at Montgomery, Montgomery, AL 36117-3596; (205) 244-3591; Fax: (205) 244-3762.

The recent name change (from the original Computer Users Group) reflects the fact that many who use computers in their teaching and research are also interested in such media as videotape, CD-ROM, and Laser Disk. There is also increasing attention paid to these media by those who have not been computer users.

Proposals for participation are invited from those who would like to present papers, serve as panel discussants, or demonstrate and discuss computer and media materials they have developed and use for teaching or research purposes. Possible topics for such participation include: research applications of new or existing hardware and software such as statistical packages, spreadsheets, optical scanners and optical character recognition programs, multimedia development packages, and language translation software; research design and planning issues related to selecting and using such hardware and software; creative classroom uses of the computer and various media; research on the impact and effectiveness of computer or media usage in lower division, upper division or graduate courses; training graduate students to use the computer and media in their teaching; and papers on the development, operation, and maintenance of computer or multimedia centers and such related issues as hardware, software, and personnel selection and planning for the future. Papers and presentations oriented to qualitative as well as quantitative applications are welcome. Proposals for other topics are invited as are submissions from all subfields of political science.

Paper and demonstration proposals should include an abstract outlining the major elements of the paper or demonstration material and specify in detail any equipment requirements.

Political Communication.* W. Russell Neuman, Fletcher School, Tufts University, Medford, MA 02155; (617) 627-3436; Fax: (617) 863-1543; russ@amt.mit.edu.

The political communication section welcomes proposals for papers and panels that cover a wide spectrum of research interests including, but not limited to: media and elections, communications policy, the changing role of the journalist, symbolic politics, international communications, media technology, structural 
and institutional analyses of public communications, political cognition, political discourse, rhetoric and narrative, media and political identity, and interpersonal communications.

Proposals which utilize comparative or interdisciplinary approaches or that develop new theoretical or methodological ground are particularly encouraged. When appropriate we will try to arrange co-sponsorship with other sections.

Transformational Politics. ${ }^{*}$ Stephen Woolpert, Department of Government, St. Mary's College of California, Moraga, CA 94575; (510) 376-4411, ext. 609; and Audrey Chapman, Program Director, Science and Human Rights Program, American Association for the Advancement of Science, 1333 H Street, N.W., Washington, DC 20005; (202) 326-6795.

What we mean by political transformation is when a society undergoes major change in some important part of its political attitudes, values, or institutions. The Transformational Politics section of the APSA is devoted to studying, analyzing, researching, and discussing the philosophical, theoretical, and comparative aspects of this phenomenon in general. As far as the United States is concerned, however, we believe that a transformational process is presently underway and we are not only analysts of it, but advocates and practitioners as well. We see the contemporary American movements in civil rights, feminism and ecofeminism, environmental protection, nonviolence and conflict resolution, participatory democracy, Green and New Age politics as being part of this transformational process.

We seek panels and papers that address the promise and performance of these (and other) components of this transformational process and period. Papers may be rigorous and systematic or theoretical and anecdotal. We also sponsor a series of support groups in the evenings during the APSA where we discuss our personal experiences, problems and challenges as those who practice this kind of politics as professors of political science-in the workplace, in politics and in our personal lives. Those who have experience as facilitators or mediators are en- couraged to write us about participating as such in the support groups.

Caucus for a New Political Science.* Joe Kling, Department of Government, St. Lawrence University, Canton, NY 13617; (315) 379-5214 or 379-5279.

The purpose of this section is to bring together those individuals who identify with a critical and activist approach to the study of political science. We seek papers across the broadest possible spectrum of the discipline. But we expect these papers will share the conviction that the study of politics is never value-free, and that political scientists, whatever their field or focus, have an active responsibility to connect their understanding to the search for human betterment and social justice.

While we have not decided upon a specific set of themes for the 1993 meeting, we are generally interested in the following areas:

(1) Currents in critical political theory, including discussions of NeoMarxism, Critical Theory, The Politics of Culture, Feminist Theory, and The Idea of a New Political Science.

(2) Contending Perspectives on Democracy and Development, including discussions of Latin America, Asia, Middle East, Africa, Women in the Third World.

(3) Racial and Ethnic Politics.

(4) The Politics of Gender.

(5) International Political Economy, Political Responses to the Globalization of the Economy, Intervention in Third World Politics.

(6) Urban Political Economy, Community Politics.

(7) Social Movements in Western Europe and America, Political Transformation in Communist Systems, Agendas for the Left.

If there are other topics or themes in which you would be interested, we invite your suggestions and proposals.

Political Psychology. Maryann K. Cusimano, Johns Hopkins University, Department of Political Science, Baltimore, MD 21218; (410) 516-7540 (W); (410) 889-6062 (H); Fax: (410) 516-5515.

Papers concerning the relationship between political and psychological processes are welcome, especially proposals for papers and panels which address the following topics: prospect theory; political cognition; the intersection between postmodernism and political psychology; the pros and cons of various methodologies of political psychology; crisis decision making; political psychology as a field of research-its definition, history, future, problems and promise. These suggestions are in no way meant to be exhaustive. We are also interested in panel proposals that can be jointly sponsored by any of the other organized sections.

\section{APSA Research Grantees Announced}

The APSA Research Support Committee announced the 1992 Research Grantees on May 1. The Council established the research grant program in 1984, and authorized $\$ 15,000$ to be distributed annually. To be eligible for a grant the applicants must be APSA members and must either be a faculty member at a non-Ph.D. granting college or university or be a political scientist not affiliated with an academic institution. Funds are used for research that addresses a significant problem in political science.

The Selection Committee, composed of Gary Jacobson, University of California-San Diego, chair; F. Chris Garcia, University of New Mexico; Timothy Tilton, Indiana University; Kathleen Knight, University of Houston; and Stanley Rothman, Smith College, reviewed 34 applicants and made 11 awards.

Karen Beckwith, The College of Wooster, "Women, Communities, and Political Movements in the United States and Great Britain"

Jeffrey Edwards, Roosevelt University, "The Resolution of an Urban Crisis: Racial Formation in Detroit, 1961-1981"

James M. Glaser, Tufts University, "Studying Political and Racial Attitudes with Contextual Data"

Robert J. Griffiths, University of North Carolina-Greensboro, "The South African Armed Forces: Democratization and Reorganization"

Rebekah Herrick, Oklahoma State 